Original Russian Text @ 2018 A.A. Dulina, S.I. Chumachenko, published in Forest Science Issues Vol. 1, No. 1, pp. 1-22

DOI 10.31509/2658-607x-2019-2-2-1-16

\title{
REVIEW OF MODELS OF FOOD RESOURCES EVALUATION OF THE FORESTS OF CENTRAL RUSSIA
}

\author{
A.A. Dulina ${ }^{1}$, S.I. Chumachenko \\ ${ }^{1}$ Center for Forest Ecology and Productivity of the RAS \\ Profsoyuznaya st. 84/32 bldg. 14, Moscow, 117997, Russia \\ ${ }^{2} \mathrm{MB}$ of Bauman Moscow State Technical University \\ $1^{\text {st }}$ Institutskaya street, 1 , \\ 141005, Mytischi, Moscow region, Russia \\ E-mail: anna_dulina@bk.ru \\ Received 25 November 2018
}

The article analyzes the most favourable conditions for the growth and fruit bearing of berries and mushrooms; studies yield indices of food resources; examines Russian and foreign yield capacity models of forest food resources. It is proposed to use illumination at the level of ground cover, which is an informative parameter, for modelling the dynamics of yield capacity of food resources. Illumination estimation will help us to more accurately assess the yield of food resources not only in single-storeyed stands with understorey trees and undergrowth, but also in multistoreyed stands.

Key words: forest food resources, modelling, illumination, yield

Currently, the area of forest lands in the center of the European Russia that are not leased for forest management is decreasing. The possibility of income growth only through the sale of wood by increasing the area of woodland holdings is almost used up, so it's necessary to find a way to get higher return on each forest plot. Multi-purpose forest management might be the optimal solution. Harvesting of wood and non-wood resources in the same forest area is not only possible, but also necessary. It is beyond dispute that harvesting of timber which is a crucial material for construction, the raw material for the pulp and paper industry and many other industries, plays an important role in the Russian economy. Yet besides wood, forests have huge resources of various products used for food and as raw material for industrial processing. Forest Code of the Russian Federation, 2006, divides these types of forest management into four groups: harvesting of galipot; harvesting and picking of non-wood forest resources including stumps, birch bark, bark of trees and shrubs, kindling, browsable forage, spruce, fir, pine or other coniferous trees boughs for the Christmas and New Year holidays, moss, forest litter, cane, reed etc.; harvesting of food forest resources including wild fruits, berries, nuts, mushrooms, seeds, birch sap etc. and the collection of medicinal plants; use of forests for hunting (Forest Code of the Russian Federation, 2006). 
Past research and practice shows that the income from the use of non-wood resources in certain types of forests is several times higher than the income from timber harvesting (Telishevsky, 1986). For example, comparative cost estimates of wood and cloudberry in sphagnum pine forest show that the income from the sale of berries per 1 ha was 11.5 times higher than the income from logging (Kositsyn, 1996, 1998). In the Komi Republic, researchers compared the cost of 120-yearold pine wood and the annual yield of ceps in the same area. It was found that in just 5 years, the income from the sale of harvested mushrooms from such a plot will be comparable to the cost of wood harvested at the age of 120 years. If the plot is used to collect mushrooms throughout the period of forest growth, the profit from those mushrooms will be several times higher than the profit from logging (Kozubov, Taskayev, 2000). Therefore, the use of non-wood forest resources increases the economic potential of the forest industry and provides population with organic products (Bolshakov, 2013).

Interest in the use of non-wood resources recently revived because forest users want to get the maximum benefit from a woodland holding. Of all possible forest resources, besides timber, food resources (berries and mushrooms) are the most in-demand on the market. Previously, forest management methods around the world have traditionally focused on wood production; however, with the transition to multi-purpose forest management it was found that assessing and forecasting the dynamic pattern of non-wood resources is a very relevant issue (Vacik et al., 2016; Huber et al., 2016). Computational modeling is one of the modern approaches to solving this problem.

The objective of this paper is to analyze the current state of assessment and forecasting of the dynamic pattern of non-wood resources and the rationale for the choice of factors and indices for modelling forest food resources for the central part of Russia.

To achieve this objective, it is necessary to (1) assess the growing conditions of the most common berries and mushrooms in the European part of Russia, (2) assess the existing models and (3) assess the possibilities of using taxation data and propose other informative indicators to calculate the yielding power of mushrooms and berries.

\section{ENVIRONMENTAL GROWING CONDITIONS OF THE MOST COMMON BERRIES AND MUSHROOMS}

Among the non-wood food resources of Russia the most important ones in the context of economic meaning of food fruits are forest plants belonging to the Vacciniaceae family - cranberry (Oxycoccus paluslris Pers), cowberry (Vaccinium vitis-idaea L.), bilberry (Vaccinium myrtillus L.) and to the Rosaceae family - raspberry (Rubus idaeus L.) and cloudberry (Rubus arcticus). The most valuable mushrooms are cep (Boletus edulus Fr. ex Bull.), rough boletus (Boletus scaber Frex Bull.), orange-cap boletus (Boletus aurantiacus Fr.), and chanterelle (Cantharellus cibarius Fr.) (Egoshina, 2005). 
Bilberry is a low-growing prosrate shrub with a wide distribution area: from the meadowsteppe zone to the marshes. It is rather common, growing from semi-open spaces to particularly shady forests. The prosrate shrub grows mainly on moist poor sandy soils, usually acidic, with a small amount of lime (Landolt, 1977; Tsyganov, 1983). Intensely dislikes direct sunlight. The optimum light regime is achieved with an average closure of canopy. Bilberry growing in pine or spruce forests is of industrial importance. After selection felling the fruiting of bilberry is increased by 2.5 times within 5 years, and then returns to the usual amount. After clear cuts, in the first 2-3 years degradation of the shrubs is observed, followed by their complete withering away that is only reversed 40-50 years later (Zworykina, 1972; Kurlovich et al., 2015).

Cowberry is an evergreen shrub with a wide area of distribution from the meadow-steppe to the swamp, forest and meadow zones. It is a light-requiring plant that grows especially well in fresh coniferous forests. This berry grows on poor acidic fine-sanded soils; cranberry prefers less moist places than bilberry (Landolt, 1977; Tsyganov, 1983). It fruits well in stands with low closure of the tree canopy and in open areas. Cowberry yield increases by 1.5 times in the first 5-7 years after the selection felling. Clear cuts result in abundant fruiting for 6-8 years followed by the depression of the berry field which restores 30-40 years later (Cherkasov et al., 1988; Kurlovich et al., 2015).

Cranberry is an evergreen prosrate shrub with an area of distribution from wet forestmeadow to marsh zones. Cranberry habitats are raised (oligotrophic) and transitional (mesotrophic) bogs. In the forest zone, it grows on moderately humid habitats on microhills, in the forest tundra it is widespread at swamps. This prosrate shrub likes acidic poor peat lands, grows in open and semiopen areas (Landolt, 1977; Tsyganov, 1983). Cranberry yield is closely connected to forest density - the highest yield is seen in low-density stands (Cherkasov et al., 1981).

Raspberry is a perennial semishrub of forest-meadow type. It grows on acidic and neutral rich soils. It can be found in both open and shaded areas (Landolt, 1977; Tsyganov, 1983). Good yields are seen in open and semi-open habitats: burnt areas, clear cut areas, and forest fringes. It takes raspberry 2-3 years to grow in fresh cut areas, and in 3-8 year-old clear cuts it reaches its maximum yield. In old clear-cut areas raspberry is inhibited by the growth of deciduous tree species (Kazantseva, Miryaminova, 2017). After the closure of the tree canopy it can be found in forests of different types in depressed state, bearing almost no fruit.

Cep grows in deciduous forests on soils rich in humus, overgrown with grass and moss. Ceps are usually found in stands with an average density. Fruiting of ceps is significantly increased in complex multi-storeyed stands (Telishevsky, 1986).

Rough boletus is the cep's closest relative growing in deciduous forests which necessarily contain birch. It has a variety of forms represented in its typical conditions. Stands with average 
density are best suited for the growth of these mushrooms. Rough boletus is most productive in middle-aged stands.

Table 1. Ranges of changes in fruiting conditions for the most valuable berries and mushrooms in Russia (Landolt, 1977; Tsyganov, 1983; Telishevsky, 1986; Cherkasov et al., 1981)

\begin{tabular}{|c|c|c|c|c|c|}
\hline $\begin{array}{l}\text { Berry dwarf shrubs / } \\
\text { mushrooms }\end{array}$ & $\begin{array}{c}\text { Forest } \\
\text { conditions } \\
\text { type }\end{array}$ & $\begin{array}{l}\text { Age of } \\
\text { stand }\end{array}$ & Species & $\begin{array}{l}\text { Optimal } \\
\text { density of the } \\
\text { forest stand }\end{array}$ & $\begin{array}{l}\text { Forest zone / } \\
\text { subzone }\end{array}$ \\
\hline Bilberry & $\begin{array}{c}\text { A3-4, } \\
\text { B3-4, } \\
\text { C3 } \\
\end{array}$ & $\begin{array}{l}60 \text { and more } \\
40 \text { and more }\end{array}$ & $\begin{array}{l}\text { Pine } \\
\text { Spruce } \\
\text { Birch } \\
\end{array}$ & $0.6-0.8$ & $\begin{array}{l}\text { Mixed and broad- } \\
\text { leaved forests zone, } \\
\text { taiga }\end{array}$ \\
\hline Cowberry & $\begin{array}{l}\text { A2-4, } \\
\text { B2-4 }\end{array}$ & 40 and more & $\begin{array}{l}\text { Pine } \\
\text { Spruce } \\
\text { Birch }\end{array}$ & $0.3-0.4$ & $\begin{array}{l}\text { Mixed and broad- } \\
\text { leaved forests, forest } \\
\text { tundra, taiga }\end{array}$ \\
\hline Cranberry & $\begin{array}{c}\text { A4-A5, } \\
\text { B4 }\end{array}$ & Various & $\begin{array}{l}\text { Pine } \\
\text { Spruce } \\
\text { Birch }\end{array}$ & $0.3-0.5$ & $\begin{array}{l}\text { Tundra and forest } \\
\text { tundra, taiga, mixed } \\
\text { and broad-leaved } \\
\text { forests zone }\end{array}$ \\
\hline Raspberry & $\begin{array}{l}\text { A3, B3, } \\
\text { C3 }\end{array}$ & - & $\begin{array}{l}\text { Pine } \\
\text { Spruce } \\
\text { Birch }\end{array}$ & Open space & $\begin{array}{l}\text { Mixed and broad- } \\
\text { leaved forests zone, } \\
\text { forest-steppe zone }\end{array}$ \\
\hline Cep & $\begin{array}{l}\text { A1-2, } \\
\text { B1-3, } \\
\text { C1-3, } \\
\text { D2-3 }\end{array}$ & $15-40$ & $\begin{array}{c}\text { Spruce, Pine } \\
\text { Deciduous, } \\
\text { Birch, } \\
\text { Oak } \\
\text { Aspen, } \\
\text { Alder } \\
\end{array}$ & $0.6-0.8$ & $\begin{array}{l}\text { Mixed and broad- } \\
\text { leaved forests zone, } \\
\text { tundra, forest tundra, } \\
\text { taiga }\end{array}$ \\
\hline Rough boletus & $\begin{array}{l}\mathrm{A} 2-5 \\
\mathrm{~B} 2-3\end{array}$ & $15-40$ & $\begin{array}{l}\text { Birch, } \\
\text { Poplar }\end{array}$ & $0.7-0.8$ & $\begin{array}{l}\text { Mixed and broad- } \\
\text { leaved forests zone, } \\
\text { tundra, forest tundra }\end{array}$ \\
\hline Orange-cap boletus & $\begin{array}{l}\text { A2-3, } \\
\text { B2-3, } \\
\text { C2-3 }\end{array}$ & $15-40$ & $\begin{array}{l}\text { Aspen, birch, } \\
\text { pine and } \\
\text { spruce, forest } \\
\text { fringes }\end{array}$ & $0.7-0.8$ & $\begin{array}{l}\text { Mixed and broad- } \\
\text { leaved forests zone, } \\
\text { tundra }\end{array}$ \\
\hline Chanterelle & $\begin{array}{l}\text { A2, } \\
\text { B2-3 }\end{array}$ & $15-40$ & $\begin{array}{c}\text { Spruce, } \\
\text { Pine } \\
\text { coniferous, } \\
\text { birch and } \\
\text { mixed } \\
\end{array}$ & $0.7-0.8$ & $\begin{array}{l}\text { Mixed and broad- } \\
\text { leaved forests zone }\end{array}$ \\
\hline
\end{tabular}

Orange-cap boletus grows in deciduous forests, aspen and birch forests on clay soil. It can also be found in stands with an average density, as well as on forest fringes and in clearings. It is believed that this mushroom most often grows together with aspen and poplar, more seldom with willow, and can also form mycorrhiza with oak, beech, hornbeam, and birch.

Chanterelle is found in coniferous and deciduous, not very dense mossy forests. It grows throughout the summer and autumn (in June - October) in clumps in coniferous, birch and mixed forests in moist places on all types of soils. It forms mycorrhiza with various trees, most often with spruce, pine, oak, and beech. 
Based on the literature data, we put together the understandings of the most favourable forest conditions for achieving the industrial-scale yield of berries and mushrooms (Table 1). Fruiting of species in different types of forest conditions (FCT) is presented in Table 2.

Table 2. Fruit formation (prosrate shrubs) and formation of fruit bodies (mushrooms) in different types of forest conditions (FCT), +- fruiting

\begin{tabular}{|c|c|c|c|c|c|c|c|c|c|c|c|c|c|c|c|c|}
\hline ResourcelFCT & A1 & A2 & A3 & A4 & A5 & B1 & B2 & B3 & B4 & C1 & C2 & C3 & C4 & D1 & D2 & D3 \\
\hline Bilberry & & & + & + & & & & + & + & & & + & & & & \\
\hline Cowberry & & + & + & + & & & + & + & + & & & & & & & \\
\hline Cranberry & & & & + & + & & & & + & & & & & & & \\
\hline Raspberry & & & + & & & & & + & & & & + & & & & \\
\hline Cep & + & + & & & & + & + & + & & + & + & + & & & + & + \\
\hline Rough boletus & & + & + & + & + & & + & + & & & & & & & & \\
\hline $\begin{array}{c}\text { Orange-cap } \\
\text { boletus }\end{array}$ & & + & + & & & & + & + & & & + & + & & & & \\
\hline Chanterelle & & + & & & & & + & + & & & & & & & & \\
\hline
\end{tabular}

\section{OVERVIEW OF MODELS OF FOREST FOOD RESOURCES YIELDS}

One of the well-known approaches to assessing the yield of non-wood resources in Russia is using tables of biological and industrial yields presented in the books Taxation manual to forest resources of Russia (besides wood) (Kurlovich, Kositsyn, 2018), and Guide to accounting and evaluation of secondary forest resources and by-products of forest management (Kurlovich et al., 2003). They include more than 500 standard and reference tables on the main types of non-wood resources of Russian forests, classified by forest vegetation zones and forest regions they are made up of; these conditions determine the growth of specific tree species as well as underbrush, grass and shrub storey and ground cover.

The tables were obtained by numerous estimates with the foundation of experimental plots to calculate the yielding power of non-wood resources. Using the tables, it is possible to forecast the yield of a non-wood resource in almost any region. If data on productivity in the studied area are lacking, the authors recommend using tables for the area with similar growing conditions.

The manual and the guide contain data on the regions of the Russian Federation, making it possible to determine the yield of food resources adjusted for the area of growth. Therefore these tables can be used for the entire territory of Russia. 
Main variables influencing yields are silvicultural and taxation characteristics of forest areas; based on these data it is possible to predict the productivity of non-wood resources with a certain degree of accuracy.

The first indicator determining the possibility of growth is the type of forest conditions. It is underpinned by edaphic factors that reflect soil fertility and moisture. For example, cranberry is an endemic species for A5 and B5 and does not grow in any other conditions. Predominant species has considerable influence on growing of certain types of resources. It is especially true for mushrooms. Some species, for example rough boletus, live in symbiosis with only one tree species, birch, whereas ceps prefer mixed forests (Pautov, 2009).

The age of stand also determines the possibility of mushroom and berry growth. The majority of forest berries (cowberry, blueberry, cloudberry, and bilberry) reach the industrial-scale amounts in forests where the stand is more than 40-60 years old. This is due to optimal light conditions and less competition with herbage plants. At the same time, mushrooms are most productive in forests where the stand is $15-40$ years old. This is due to forest litter thickness: the thinner it is, the faster it warms up, while mushrooms need heat to grow (Zhukova et al., 2008).

Density of forest stand is one of the limiting factors for the growth of berries and mushrooms and the one on which the yield depends. Density influences the amount of light, heat and precipitation getting beneath the forest canopy as well as the composition and development of plants that can compete with berry prostrate shrubs (Malinovskikh, 2017). The explanation may be that if the stand is very dense, plants can't grow because of lacking light and impossibility to photosynthesize. If the density is low, there is a large number of competitive species that crowd out berry prostrate shrubs. For instance, bilberry does not stand direct sunlight, the optimal light mode for it is created at the density of 0.6-0.8 (Nikitenko, 2016). Cowberry, cloudberry and cranberry are more light-requiring, they bear fruit well at the stand density of $0.3-0.5$ and in open places (Gorobets, Slavsky, 2013).

Stands with the density of $0.7-0.8$ are optimal for fruiting of all types of mushrooms (Yurkina, 2017). Mushrooms also need light during spore maturation. Thus, the majority of berries and mushrooms depend on a certain light mode, which is taken into account in the taxation manual in the form of stand density. The tables of the manual, however, ignore complex stands with several storeys. The flow of light reaching the ground cover will be several times lower in a multi-storeyed stand than in a pure stand of the same density, which means, that the yielding power of berries and mushrooms will not be the same. Therefore it might be not quite right to use the indicator of density which influences the yielding power of berries and mushrooms, and not to take light into account.

On the basis of stand density and species composition of the 1st and 2nd storeys, understorey trees and underbrush it is possible to determine illumination as a more informative 
factor influencing the development of berries and mushrooms. The light intensity will then be considered not at the level of the upper storey, but at the level of ground cover, which will allow us to assess the yielding power and growth prospects of the grass and shrub storey more accurately and to give recommendations on how to improve the conditions for forest management focusing on many resources.

We should not ignore the influence of forest management activities on various forest food resources. Forest felling is one of the most important industry-related and anthropogenic factors in terms of its impact on forest biogeocenoses. Partial or complete removal of trees affects light and temperature conditions not only causing significant changes in the tree canopy but also leading to the disturbance of all other storeys of plant and soil cover (Kurlovich et al., 2015). Adequate cuttings can help to increase the yielding power of the resource of interest.

There are species that achieve industry-scale yield only at open areas (clear cut areas, burnt areas, forest fringes), including i.e. European raspberry. This is why raspberry is actively growing and bearing fruit on plots affected by clear cuts.

For berries that grow beneath the forest canopy the optimal measure would be forest thinning to the density at which the greatest yields are achieved. It is necessary to pay attention to the pattern of regeneration after felling. For fruiting of all types of mushrooms mixed stands with the density of 0.7-0.8 are optimal (Bulgakov et al., 1987). Therefore thinnings, especially liberation and disengagement cuttings are to be done on time.

Thinnings help increasing light and heat inflow to the lower phytocenosis storeys, while increasing soil moisture contribute to a microclimate favourable for mushroom fruiting. In complex fresh and moist subors liberation and disengagement cuttings of young stands let grasses, especially cereals, grow, which hinders fruit bearing of mushrooms. When thinning, the density should be reduced to 0.6-0.7, leaving up to 3 deciduous plants in coniferous stands (Klyuchnikov, 2005). After clear cuts of coniferous or deciduous forests their light and temperature conditions on the soil surface change dramatically. In the second year already the plot is overgrown with herbs. Most forest mushrooms start to grow later, when a young forest emerges on the clear cut area. Therefore, in the setting of multi-purpose forest management it is possible to control the yield of food resources (Obydennikov, 2002).

Growing interest in multi-purpose forest management in order to increase the profitability of a forest plot means that it is necessary to make joint forecasts on the use of both wood and nonwood food resources, which is impossible without modelling.

The transition to multi-purpose forest management has already begun around the world. In Finland, there are a lot of studies on bilberry yields in different growing conditions, taking into account a large number of factors (precipitation, temperature, humidity, forest type, stand age) that 
affect productivity (Wallenius, 1999; Turtiainen et al., 2007, 2012). The dependence of the yield on these factors is demonstrated: middle-aged stands with optimal humidity were found to be best suited for berries to bear fruit. Also, the yielding power is affected by accumulated temperatures.

Empirical models of berry yielding power developed before 2009 were based on regional data on yields in North Karelia (Ihalainen et al., 2003, 2005). Models for Bilberry Yield and Models for Cowberry Yields are used to estimate the yields of bilberry and cowberry. The input parameters are stand age and type. Then the models for bilberry and cowberry yields were calibrated using field data on the yields in southern Finland. These models, however, did not take into account the projective cover of bilberry as a parameter determining the yield. Using the Stand simulator MOTTI made it possible to model the yield of bilberry on different soils in northern and southern Finland (Hynynen, 2003, 2005).

A set of empirical models was developed in 2009 (Miina et al. 2009) predicting first the area of bilberry projective cover - Model for the Percentage Coverage of Bilberry (Model 1) and then the annual yield of berries depending on the stand features - Models for Bilberry Yield (Model 2). Models also allow us to see annual fluctuations in yield forecasts. The models focused exclusively on mineral soil plots (Miina et al., 2010). A model which includes not only mineral but also peat soils was developed in 2014. Then, annual fluctuations of bilberry yield in 2001-2014 were modelled using a much larger data set from MASI, data on permanent experiment areas in Finland. The Finnish name MASI literally means berries (MArja) and mushrooms (SIeni) system, and it consists of a number of different databases. Model 1 was designed to predict the average area of bilberry projective cover based on constant indicators - age, bonitet, and FCT. Model 2 predicts the average amount of bilberry in a stand. Input data include the area covered by bilberry, height of stand and average effective temperature. In 2015, the average annual yield of bilberry for 19972013 was calculated using data from MASI (Turtiainen et al., 2011, 2016). Similar models making forecasts in two stages - first the projective cover area and then the yield - were also developed for cowberry: Model for the percentage coverage of cowberry and Model for cowberry yield (Turtiainen et al., 2005, 2013).

Other countries have developed a number of models for species of the Vaccinium genus. For the French forests, the Model the cover/abundance of Vaccinium myrtillus was used that takes into account climatic and edaphic factors (temperature, precipitation, solar radiation, water balance, soil $\mathrm{pH}$ and $\mathrm{C} / \mathrm{N}$ ratio) to predict bilberry yield (Coudun, Gegout, 2007). In Canada, bilberry and blueberry models have been developed to predict yields using climate variables (Hall et al., 1982). In Sweden, various ecosystem services including bilberry production have been modelled in order to make forecasts using stand features, climatic and edaphic factors (Gamfeldt et al., 2013). 
Mushrooms are an equally important food resource. Empirical models for forecasting the yield of forest mushrooms: Empirical models for predicting the production of wild mushrooms (Bonet et al., 2008) were designed. Main factors affecting the yielding power are taxation features of forest stands (species - common pine, age, height, area, number of trees per hectare, average diameter, age class). However, mushroom production also depends on weather conditions such as time and amount of precipitation which cannot be accurately predicted in a long-time forecast.

Then, several more factors are added to the models. Terrain affects the predicted production of mushrooms, likely due to the presence of groundwater. Water is the greatest growth limiting factor in the forests of southern Central Pyrenees, where light is abundant and temperatures are mild all year round. Moreover, the model shows the dependence of the mushroom yielding power on the nature of forest restoration: mushroom yield is higher in case the regeneration is natural (Bonet et al., 2010).

In 2014, an expert model of cep yield in the northern Karelian spruce forests was developed in Finland - Expert model for Boletus edulis. 25 experts in cep yield assessment were involved. In addition to the environmental factors (precipitation, temperature and nutrients, ground vegetation) and the state of the stand, the experts also visually assessed the forest based on forest stand pictures (Tahvanainen et al., 2014).

In Spain, a model of forecasting the yield of mushrooms of the Russulaceae family (Lactarius) with two stages of modelling was developed. At the first stage, the probability of mushrooms appearing in the stand is analyzed - Models for the probability of mushroom occurrence, and at the second stage their yield is forecasted - Models for mushroom yield conditional on the probability of mushroom occurrence. Growth conditions for mushrooms are based on the features of climate, soil, stand composition and age. The amount and distribution of precipitation as well as soil $\mathrm{pH}$ are the main factors influencing the yielding power (Tay et al., 2016).

The Russian model FORRUSS-S (FORest of RUSsia - Stand) is designed to forecast the dynamic pattern of taxation features of multispecies all-aged stands in an area of up to hundreds of thousands of hectares (Chumachenko, 1993; Chumachenko et al., 2003). This model is an ecological-physiological (explanatory), spatially-oriented model of stands under different scenarios of forest management. The model generates new taxation descriptions (with a 5-year interval), on the basis of which external modules allow evaluating many additional characteristics including forest food resources.

Comparison of the features of non-wood forest resource models is presented in Table 3. 
Table 3. Classification of non-wood resource models

\begin{tabular}{|c|c|c|c|c|c|c|c|}
\hline Model name & $\begin{array}{l}\text { Simulated } \\
\text { resource }\end{array}$ & Input parameters & Year & Region & $\begin{array}{c}\text { Spatial } \\
\text { level }\end{array}$ & $\begin{array}{l}\text { Simulated } \\
\text { indicator }\end{array}$ & Authors \\
\hline $\begin{array}{l}\text { Models for Bilberry Yield. } \\
\text { Models for Cowberry } \\
\text { Yields. } \\
\text { (Ihalainen et al., 2003, } \\
\text { 2005) }\end{array}$ & $\begin{array}{l}\text { Bilberry } \\
\text { Cowberry }\end{array}$ & $\begin{array}{l}\text { Age, type of } \\
\text { forest growth } \\
\text { conditions }\end{array}$ & 2003 & $\begin{array}{l}\text { North } \\
\text { Karelia }\end{array}$ & Local & Yield & $\begin{array}{l}\text { M. Ihalainen, K. } \\
\text { Salo, T. Pukkala }\end{array}$ \\
\hline $\begin{array}{l}\text { Stand simulator MOTTI } \\
\text { (Hynynen 2003, 2005) }\end{array}$ & Bilberry & $\begin{array}{l}\text { Age, FCT, soil } \\
\text { type }\end{array}$ & 2005 & $\begin{array}{l}\text { Northern } \\
\text { and } \\
\text { southern } \\
\text { Finland }\end{array}$ & Local & Yield & $\begin{array}{l}\text { J. Hynynen, } \\
\text { R. Ojansuu }\end{array}$ \\
\hline $\begin{array}{l}\text { Model for the Percentage } \\
\text { Coverage of Bilberry } \\
\text { Models for Bilberry Yield } \\
\text { (Miina et al., 2009, 2010) }\end{array}$ & Bilberry & $\begin{array}{c}\text { Age, FCT, } \\
\text { mineral soils }\end{array}$ & 2009 & $\begin{array}{c}\text { Southern } \\
\text { Finland }\end{array}$ & Local & $\begin{array}{c}\text { Projective cover } \\
\text { area, } \\
\text { yield }\end{array}$ & $\begin{array}{l}\text { J. Miina, } \\
\text { J.-P.Hotanen, } \\
\text { K. Salo } \\
\text { T. Pukkala }\end{array}$ \\
\hline $\begin{array}{l}\text { Model for the percentage } \\
\text { coverage of cowberry } \\
\text { Model for cowberry yield } \\
\text { (Turtiainen et al., 2005, } \\
\text { 2013) }\end{array}$ & Cowberry & $\begin{array}{c}\text { Age, bonitet, } \\
\text { FCT, } \\
\text { Height } \\
\text { Projected } \\
\text { coverage area, } \\
\text { average effective } \\
\text { temperature } \\
\end{array}$ & 2014 & Finland & $\begin{array}{c}\text { Local } \\
\text { Regiona } \\
1\end{array}$ & $\begin{array}{l}\text { Projective } \\
\text { cover area, } \\
\text { yield }\end{array}$ & $\begin{array}{l}\text { M. Turtiainen, J. } \\
\text { Miina, K. Salo, } \\
\text { J.-P Hotanen }\end{array}$ \\
\hline $\begin{array}{l}\text { Model for the Percentage } \\
\text { Coverage of Bilberry } \\
\text { Models for Bilberry Yield } \\
\text { (Turtiainen et al.,2016) }\end{array}$ & Bilberry & $\begin{array}{l}\text { Age, bonitet, } \\
\text { FCT, } \\
\text { Height } \\
\text { Projective cover } \\
\text { area, average } \\
\text { effective } \\
\text { temperature }\end{array}$ & 2016 & Finland & $\begin{array}{c}\text { Local } \\
\text { Regiona } \\
1\end{array}$ & $\begin{array}{c}\text { Projective } \\
\text { cover area } \\
\text { yield }\end{array}$ & $\begin{array}{l}\text { M. Turtiainen, J. } \\
\text { Miina, } \\
\text { K. Salo, } \\
\text { J.-P Hotanen }\end{array}$ \\
\hline $\begin{array}{l}\text { Model the cover/abundance } \\
\text { of Vaccinium myrtillus } \\
\text { (Coudun, Gegout, 2007) }\end{array}$ & Bilberry & $\begin{array}{l}\text { Age, stand } \\
\text { composition, } \\
\text { solar radiation, } \\
\text { temperature, } \\
\text { precipitation, } \\
\text { soil type and } \\
\text { moisture } \\
\end{array}$ & 2007 & $\begin{array}{l}\text { Central } \\
\text { France }\end{array}$ & Local & Yield & $\begin{array}{l}\text { C. Coudun, } \\
\text { J. Gegout }\end{array}$ \\
\hline $\begin{array}{l}\text { Empirical models for } \\
\text { predicting the production of } \\
\text { wild mushrooms (Bonet et } \\
\text { al., 2008) }\end{array}$ & Mushrooms & $\begin{array}{c}\text { Taxation } \\
\text { characteristics } \\
\text { (Pine) }\end{array}$ & 2008 & $\begin{array}{c}\text { Spain } \\
\text { (Central } \\
\text { Pyrenees) }\end{array}$ & Local & Yield & $\begin{array}{l}\text { J.A. Bonet, } \\
\text { M. Palahi, } \\
\text { C. Colinas, } \\
\text { T Pukkala, C.R. } \\
\quad \text { Fischer }\end{array}$ \\
\hline $\begin{array}{l}\text { Empirical models for } \\
\text { predicting the production of } \\
\text { wild mushrooms (Bonet et } \\
\text { al., 2010) }\end{array}$ & Mushrooms & $\begin{array}{c}\text { Taxation } \\
\text { characteristics } \\
\text { (Pine), terrain }\end{array}$ & 2010 & \begin{tabular}{|c|} 
Spain \\
(Central \\
Pyrenees \\
and north- \\
eastern \\
Spain) \\
\end{tabular} & Local & Yield & $\begin{array}{l}\text { J.A. Bonet, M. } \\
\text { Palahi, T Pukkala, } \\
\text { C.R. Fischer J. } \\
\text { Martínez de Aragór }\end{array}$ \\
\hline $\begin{array}{l}\text { Expert model for Boletus } \\
\quad \text { edulis } \\
\text { (Tahvanainen et al., 2014) }\end{array}$ & Cep & $\begin{array}{c}\text { Stand } \\
\text { composition, } \\
\text { precipitation, } \\
\text { temperature, } \\
\text { pictures }\end{array}$ & 2014 & Finland & Local & Yield & $\begin{array}{l}\text { V. Tahvanainen, } \\
\text { M. Kurttila, } \\
\text { J. Miina, K. Salo }\end{array}$ \\
\hline $\begin{array}{l}\text { Models of probability of } \\
\text { mushroom growth } \\
\text { Models of mushroom yield } \\
\text { are based on the probability } \\
\text { of } \\
\text { mushroom growth } \\
\text { Models for the probability } \\
\text { of mushroom occurrence } \\
\text { (Taye et al., 2016) }\end{array}$ & Russelaceae & $\begin{array}{l}\text { Stand } \\
\text { composition and } \\
\text { age, soil type, } \\
\text { climatic } \\
\text { conditions }\end{array}$ & 2016 & $\begin{array}{l}\text { Central } \\
\text { Spain }\end{array}$ & Local & $\begin{array}{l}\text { Probability of } \\
\text { growth, } \\
\text { yield }\end{array}$ & $\begin{array}{l}\text { Z.M. Taye, } \\
\text { F. Martínez-Peña, } \\
\text { J.A. Bonet, } \\
\text { J . Martínez } \\
\text { de Aragón, } \\
\text { S De-Miguel }\end{array}$ \\
\hline $\begin{array}{l}\text { Model of the dynamic } \\
\text { patterns of multispecies all- } \\
\text { aged forest areas - } \\
\text { FORRUSS-S } \\
\text { (Chumachenko, 1993) }\end{array}$ & $\begin{array}{c}\text { Berries, } \\
\text { Mushrooms }\end{array}$ & $\begin{array}{c}\text { Taxation } \\
\text { characteristics, } \\
\text { FCT, light. } \\
\text { climatic conditions }\end{array}$ & 1993 & Russia & Local & Yield & S.I. Chumachenko \\
\hline
\end{tabular}


The vast majority of the presented foreign models (Finland) is designed and function mainly with single-species stands. No methods of work proposed for multispecies stands could be found in the literature. Stands change over time, and stand density, composition, age and other parameters will change accordingly (Isaev, 2013). Therefore, it is necessary to model the yield of non-wood resources taking into account the dynamics of forest stand features including changes caused by anthropogenic factors. It is thus necessary to integrate the model of dynamics of stand features and the model of evaluation of non-wood forest resources.

It is planned to use the FORRUS-S model of dynamics of the main taxation indicators of multi-species all-aged forests to assess the changes in commercially available forest resources of the central part of European Russia.

Let us describe the FORRUS-S model in detail. The input data of the model are: standard taxation descriptions of strata, stand plans, bio-ecological data bases (growth rates at different ontogenetic states, the attitude to the light, seed and coppice productivity, etc.). A 5-years interval was chosen for modeling, based on the data of population biology about the time needed for the noticeable changes to occur in the growth rate, development and relations of woody plants to light in youth. The Modelling block consists of two models: Natural development and Exogenous influences.

The Natural development model of stands imitates the essential processes that take place in forest stands: natural regeneration, growth, and spontaneous thinning. Modelling makes it possible to forecast changes in average taxation parameters of stands by forest cohorts (elements), i. e. height, diameter, density, stock volume etc. as well as changes in the species and age composition of each forest stratum. Increments are calculated based on light conditions in the three-dimensional simulated space, taking into account the position of the cohort in the forest canopy and potential growth rates determined by the type of forest growth conditions.

An important role is played by the Exogenous effects block which allows simulating a large number of biotic and abiotic effects that are external to the forest cenosis. Abiotic effects include: most types of forestry activities (clear cuts and selection fellings, planting and taking care of forestry crops, thinnings of various intensity etc.), hydrotechnical melioration, fertilization, etc.

The model can be expanded with additional modules, including a module on food resource accounting which we plan to use in our work.

\section{CONCLUSION}

Currently, the trend towards multi-purpose forest management has increased. The reason is that the management aimed at obtaining wood can also result in additional income from other forest products, for example through picking wild berries and mushrooms. This is why there is a need to model joint production of wood and forest food resources. 
This article presents the conditions of growth and fruiting of the most valuable mushrooms and berries of the center of the European Russia: they turned out to be FCTs A2, A3, B2, and B3. The influence of forestry activities such as clear cuts and selection fellings of mature and overmature stands as well as thinnings on the yield of certain species of berries and mushrooms is considered.

The analysis of Russian and foreign literature showed that the yielding power of forest food resources within one forest area is closely related to the type of forest conditions, species, age and density, i.e. taxation data, the dynamics of which is predicted by the majority of forest models. The problem of non-wood resources estimation in mixed stands was revealed, as the considered models of calculating mushroom and berry yield are only true for pure same-age stands. Evaluation of food resources in mixed stands requires taking into account the share of species that form the forest stand.

Density of the tree storey is not always a significant factor of berry and mushroom yielding power. The dependence of yielding power on the density is disturbed in the presence of the second storey, understorey trees or underbrush; therefore when creating models of food resource dynamics it is proposed to take into account the illumination level under the trees' crowns, which determines the economic yielding power of the stock of berries.

\section{ACKNOWLEDGEMENTS}

The study was carried out as part of the FP7 ERA - Net Sumforest-POLYFORES project with the financial support of the Ministry of science and higher education of the Russian Federation (project unique identifier RFMEFI61618X0101), the results of the study were processed by of state assignment "Methodical approaches to the assessment of the structural organization and functioning of forest ecosystems"№ AAAA-A18-118052400130-7.).

\section{REFERENCES}

Bol'shakov B.M. Sostojanie i perspektivy ispol'zovanija nedrevesnyh resursov lesa (State and prospects for the use of non-timber forest resources), Pushkino: VNIILM, 2014, pp. 7-11.

Bonet J.A., Palahi M., Colinas C., Pukkala T., Fischer C.R., Miina J., Martínez de Aragón J. Modelling the production and species richness of wild mushrooms in pine forests of Central Pyrenees in northeastern Spain, Canadian Journal of Forest Research, 2010, Vol. 40, No. 2, pp. 347-356.

Bonet J.A., Pukkala T., Fischer C.R., Palahi M., Martínez de Aragón J., Colinas C. Empirical models for predicting the production of wild mush-rooms in Scots pine (Pinus sylvestris) forests in the Central Pyrenees, Annals of Forest Science, 2008, Vol. 65, No. 2, pp. 1-8.

Bulgakov N.K., Koz'jakov S.N., Fesjuk A.V. Tehnologija zagotovki $i$ pererabotki nedrevesnyh resursov lesa (Technology of harvesting and processing of nontimber forest resources), Moscow: Lesnaja promyshlennost', 1987, 224 p. 
Cherkasov A.F., Butkus V.F., Gorbunov A.B. Kljukva (Cranberry), Moscow: Lesnaja promyshlennost', 1981, $214 \mathrm{p}$.

Cherkasov A.F., Shutov V.V., Mironov K.A. Vosstanovlenie zaroslej brusniki i cherniki posle sploshnyh rubok (Restore thickets of lingonberry and blueberry after clear cutting), Lesovedenie, 1988, No. 4, pp. 42-48.

Chumachenko S.I. Bazovaja model' dinamiki mnogovidovogo raznovozrastnogo lesnogo cenoza (The basic model of the dynamics of multiple species of different age forest cenosis), Voprosy jekologii i modelirovanija lesnyh jekosistem, Moscow: MLTI, 1993, No. 248, pp. 147-180.

Chumachenko S.I., Korotkov V.N., Palenova M.M., Politov D.V. Simulation modelling of long-term stand dynamics at different scenarios of forest management for coniferous - broad-leaved forests, Ecological Modelling, 2003, Vol. 170, No. 2-3, pp. 345-361.

Coudun C., Gegout J. Quantitative prediction of the distribution and abundance of Vaccinium myrtillus with climatic and edaphic factors, Journal of Vegetation Science, 2007, No 18, pp. 517-524.

Cyganov D.N. Fitoindikacija jekologicheskih rezhimov v podzone hvojno-shirokolistvennyh lesov (Phytoindication of ecological regimes in the subzone of coniferous-deciduous forests), Moscow: Nauka, 1983, 196 p.

Egoshina T.L. Nedrevesnye rastitel'nye resursy Rossii (Non-timber plant resources of Russia), Moscow: NIA-Priroda, 2005, 80 p.

Gamfeldt L., Snäll T., Bagchi R. Higher levels of multiple ecosystem services are found in forests with more tree species, Nature Communications, 2013, Vol. 4 No.1340, pp. 1-8.

Gorobec V.A., Slavskij V.A. Nedrevesnaja produkcija lesa (Non-wood forest products), Voronezh: VGU imeni G.F. Morozova, 2013, 169 p.

Hall I.V., Aalders L.E., McRae K.B. Lowbush blueberry production in eastern Canada as related to certain weather data, Canadian Journal of Plant Science, 1982, Vol. 62, No.3, pp. 809812.

http://www.consultant.ru/document/cons_doc_LAW_64299/ (2018, 17 November).

Huber P., Kurttila M., Hujala T., Wolfslehner B., Vacik H. Managing for NWFPs - an assessent on the forest holding level // Wild Forest Products in Europe. Barcelona, 13-14 October, 2016, Barcelona: European Forest Institute, 2016. p. 9.

Hynynen J., Ahtikoskib A., Siitonen J., Sievaonen R., Liski J. Applying the MOTTI simulator to analyse the effects of alternative management schedules on timber and non-timber production, Forest Ecology and Management, 2005, Vol. 207, No. 1-2. pp. 5-18. 
Hynynen J., Ojansuu R. Impact of plot size on individualtree competition measures for growth and yield simulators, Canadian Journal of Forest Research, 2003, Vol. 33. No. 3, pp. 455465.

Ihalainen M., Pukkala T., Saastamoinen O. Regional expert models for bilberry and cowberry yields in Finland, Boreal Environment Research, 2005, No 10, pp.145-158.

Ihalainen M., Salo K., Pukkala T. Empirical prediction models for Vaccinium myrtillus and V. vitis-idaea berry yields in North Karelia, Silva Fennica, 2003, Vol. 37, No. 1, pp. 95-108.

Isaev A.S., Rysin L.P., Smirnova O.V. Raznoobrazie i dinamika lesnyh jekosistem Rossii (Diversity and dynamics of forest ecosystems of Russia), Moscow, Tovarishhestvo nauchnyh izdanij KMK, 2013, 478 p.

Jurkina E.V. Resursnyj potencial nedrevesnoj produkcii lesa (Resource potential of nontimber forest products), Syktyvkar: SLI, 2017, 240 p.

Kazanceva M.N., Mir'jaminova L.R. Plodonoshenie maliny obyknovennoj (Rubus idaeusl.) $\mathrm{v}$ lesah na juge tjumenskoj oblasti (Fruiting raspberry ordinary (Rubus idaeusl.) In the forests in the south of the Tyumen region), Aktual'nye problemy lesnogo kompleksa, 2017, No. 47, pp.1-4.

Kljuchnikov L.Ju. Pobochnoe lesopol'zovanie (Secondary forest management) Moscow: GOU VPO MGUL, 2005, 68 p.

Kosicyn V.N. Jekonomicheskaja ocenka resursov dikorastushhih jagodnikov (Economic valuation of wild berry resources), Rastitel'nye resursy, 1998, Vol. 34, No. 4, pp. 76-81.

Kosicyn V.N. Stoimostnaja ocenka resursov moroshki v podzone juzhnoj tajgi (Cost estimate of cloudberry resources in the southern taiga subzone), Lesohozjajstvennaja informacija, 1996, No. 12, pp. 18-23.

Kozubov G.M., Taskaev A. I. Lesnoe hozjajstvo i lesnye resursy Respubliki Komi (Forestry and forest resources of the Komi Republic), Moscow: "Dizajn. Informacija. Kartografija", 2000, $512 \mathrm{p}$.

Kurlovich L.E, Nikolaev A.F., Cherkasov V.N., Kosicyn G.V. Rukovodstvo po uchetu $i$ ocenke vtorostepennyh lesnyh resursov i produktov pobochnogo lesopol'zovanija (Guidance on accounting and valuation of secondary forest resources and secondary forest products), Pushkino: VNIILM, 2003, 315 p.

Kurlovich L.E., Kosicyn V.N. Taksacionnyj spravochnik po lesnym resursam Rossii (za iskljucheniem drevesiny), Pushkino: VNIILM, 2018, 282 s.

Kurlovich L.E., Pankov V.B., Kivileva I.M. Vlijanie lesohozjajstvennoj dejatel'nosti na sostojanie i produktivnost' pishhevyh i lekarstvennyh rastenij (The impact of forestry activities on the state and productivity of food and medicinal plants), Lesohozjajstvennaja informacija, 2015, No. 2, pp. 24-34. 
Landolt E., Okologische Zeigerwerte zur Schweizer Flora, Veroffentlichungen des Geobotanischen Instituts der ETH, Stiftung Rubel, Zurich, 1977, Vol. 64, pp. 208.

Malinovskih A.A. Vlijanie urovnja osveshhennosti pod pologom lesa na urozhajnost' cherniki v uslovijah Sredne-obskogo bora Altajskogo kraja (Possession of the lightness of illumination under the forest canopy on the yield of blueberries in the conditions of the Middle $\mathrm{Ob}$ forest of the Altai Territory), Vestnik Altajskogo gosudarstvennogo agrarnogo universiteta, 2017, Vol. 6, No. 152, pp. 87-92.

Miina J., Pukkala T., Hotanen J.-P., Salo K. Optimizing the joint production of timber and bilberries, Forest Ecology and Managemen, 2010, Vol. 259, Issue 10, pp. 2065-2071.

Miina J., Hotanen J.-P., Salo K. Modelling the abundance and temporal variation in the production of bilberry (Vaccinium myrtillus L.) in Finnish mineral soil forests, Silva Fennica, 2009, Vol. 43, No 4, pp. 577-593.

Nikitenko E.B. Nedrevesnye resursy lesa (Non-timber forest resources), Irkutsk: Izd-vo BGU, 2016, 222 p.

Obydennikov V.I., Avdeev A.N., Avdeev Je.N. Ispol'zovanie i vosproizvodstvo resursov jagodnikov v svjazi s rubkami v sel'skih lesah Novgorodskoj oblasti (Use and reproduction of berry resources in connection with logging in rural forests of the Novgorod region), Lesohoz. Inform, 2002, No. 10, pp. 15-21.

Pautov J.A., Zasuhin D.P. Rekomendacii po vydeleniju uchastkov massovogo sbora gribov $i$ jagod mestnym naseleniem (Recommendations for the allocation of sites for the massive collection of mushrooms and berries by the local population.), Syktyvkar: Komi regional'nyj nekommercheskij fond "Serebrjanaja tajga", 2009, 17 p.

Tahvanainen V., Kurttila M., Miina J., Salo K. Predicting the yields of commercially important mushrooms in Finland, Symposium on wild forest mushrooms and other NTFPs: Innovations and perspectives, La Pocatiere, 27-28 August 2014, La Pocatiere: Centre for Forest Research, 2014, pp.1-11.

Taye Z.M., Martínez-Peña F., Bonet J.A., Martínez de Aragón J., De-Miguel S. Meteorological conditions and site characteristics driving edible mushroom production in Pinus pinaster forests of Central Spain, Fungal Ecology, Vol. 23, 2016, pp. 30-41.

Telishevskij D.A. Kompleksnoe ispol'zovanie nedrevesnoj produkcii lesa (Integrated use of non-timber forest products ), Moscow: Lesnaja promyshlennost', 1986, $261 \mathrm{p}$.

Turtiainen M., Miina J., Salo K., Hotanen J.-P. Empirical prediction models for the coverage and yields of cowberry in Finland, Silva Fennica, 2013, Vol. 47, No. 3, pp. 1-22.

Turtiainen M., Miina J., Salo K., Hotanen J.-P. Modelling the coverage and annual variation in bilberry yield in Finland, Silva Fennica, 2016, Vol. 50, No. 4, pp.1-12. 
Turtiainen M., Nuutinen T. Evaluation of information on wild berry and mushroom markets in European countries, Small-scale Forestry, 2012, Vol. 11, No. 1, pp. 131-145.

Turtiainen M., Salo K., Saastamoinen O. Model-based estimates of regional and national bilberry and lingonberry yields on mineral soils in Finland, Finland: Research Notes, 2005, 44 p.

Turtiainen M., Salo K., Saastamoinen O. National and regional estimates of blueberry (Vaccinium myrtillus L.) and lingonberry (V. vitis-idaea L.) yields on peatlands in Finland, Finnish Peatland Society Helsinki, 2007, Vol. 58, No. 3-4, pp. 87-98.

Turtiainen M., Salo K., Saastamoinen O. Variations of yield and utilisation of bilberries (Vaccinium myrtillus L.) and cowberries (V. vitis-idaea L.) in Finland, Silva Fennica, 2011, Vol. 5, No. 2, pp. 237-251.

Vacik, H., Huber P., Kurttila M., Hujala T., Wolfslehner B., la Sánchez-González M., Pasalodos-Tato M., de Miguel S., Bonet J.A., Marques M., Borges J.G., Enescu M.C., Dinca L. Comparing the potential of on-Wood Forest Products across case studies in Europe, Conference on Non-Timber Forest Products and Bioeconomy, Rovaniemi, 28-30 November, 2017, Helsinki: Natural Resources Institute Finland, 2017, pp. 201-204.

Wallenius T.H. Yield variations of some common wild berries in Finland in 1956-1996, Annales Botanici Fennic, 1999, No 36, pp. 299-314.

Zhukova A.I., Grigor'ev I.V., Grigor'eva O.I., Ledjaeva A.S. Lesnoe resursovedenie (Forest Resource Management), St. Petersburg: SPb GLTA, 2008, 215 p.

Zvorykina K.V. Vlijanie vyrubki na urozhajnost' cherniki (Impact of logging on blueberry yield), Kirov: Vsesojuznyj nauchno-issledovatel'skij institut ohotnich'ego hozjajstva i zverovodstva, 1972, pp.17-19.

Reviewer: DSc in biology Chertov O.G. 